\title{
Instruments for Sustainable Tourism Development in Bosnia and Herzegovina
}

\author{
Nemanja Šarenac \\ University of East Sarajevo, Faculty of Economics Pale, Bosnia and Herzegovina \\ nemanja.sarenac@ekofis.ues.rs.ba \\ Mladen Rebić \\ University of East Sarajevo, Faculty of Economics Pale, Bosnia and Herzegovina \\ rebicmladen@yahoo.co.uk \\ Milica Bojat \\ University of East Sarajevo, Faculty of Economics Pale, Bosnia and Herzegovina \\ milicabojat@yahoo.com
}

Sustainable tourism development is based on ecological sustainability, ways of using renewable and non-renewable resources, and socio-cultural and economic sustainability. Stakeholders of the tourism sector have an important role in tourism development, in which the public represents one of the critical segments of sustainable tourism development. This paper aims to analyse and determine the most effective way of sustainable tourism development for Bosnia and Herzegovina. Understanding different approaches to tourism development and their inclusion in the process can significantly increase the sustainability of future tourism development. The research was conducted as a population survey on the entire territory of Bosnia and Herzegovina. The sample size was appropriate, based on the total population and included more than 385 respondents of different demographic categories. The main hypothesis of this paper emphasises that citizens' education about the significance of the concept of sustainable tourism represents a fundamental approach for the further development of tourism in Bosnia and Herzegovina. The analysis of the approach to sustainable tourism development has shown that most respondents consider the reduction of environmental pollution as the most critical instrument for sustainable tourism development in Bosnia and Herzegovina. They also emphasise the importance of providing the active participation of all stakeholders in the creation of tourism products, with a particular emphasis on local governments. In accordance with the obtained research results, it was concluded that the main hypothesis was not confirmed.

Keywords: sustainable development, economic sustainability, socio-cultural sustainability, ecological sustainability, cultural heritage

https://doi.org/10.26493/2335-4194.12.207-217

\section{Introduction}

Today, the sustainable tourism concept is considered to be a crucial link to the economic growth and de- velopment of a country. Mihalic (2016) concludes that the concept of responsible tourism is gaining increasing attention from scholars in the tourism domain. Ac- 
cordingly, we can confirm the existence of many definitions that put social equity and environmental quality into their focus. Pearce, Markandya, and Barbier (1991) list more than twenty definitions of sustainable tourism. The term 'sustainable tourism' was first defined by the United Nation World Tourism Organization (UNWTO) in 1996: 'Tourism that leads to the management of all areas, in such a way that the economic, social and environmental needs are fulfilled by cultural integration, ecological processes, biodiversity and support for the development of society' (Fennel, 2003). UNWTO also specifies that sustainable tourism considers the needs of current tourists as well as the needs of future generations. Buckley (2009) lists the most important activities that characterise sustainable tourism:

- optimal usage of natural resources, adequate management of environmental processes, and efforts to preserve biodiversity;

- respecting the socio-cultural attitudes of the local community, preserving cultural and traditional values, as well as undertaking activities in the field of intercultural understanding and tolerance;

- providing real and long-lasting economic processes that would enable the growth of the welfare of society, employment stabilisation, and opportunities to earn income;

- the long-term success of tourism depends on whether the tourism sector is able to manage and reconcile economic, social and environmental aspects, which, at the same time, represent the dimensions of sustainable development.

The underlying assumptions of sustainable tourism are precisely formulated in international documents, such as the Charter for Sustainable Tourism (see http: //www.gdrc.org/uem/eco-tour/charter.html) and the Global Sustainable Tourism Council (see http://www .gstcouncil.org/gstc-criteria).

Vehbi (2012) mentioned that sustainability as a concept stands for long term economic, environmental, and community health. Wearing and Nail (2012) define the dimensions of sustainable tourism development in the following way: ecological dimension - en- vironmental quality and natural resources quality create the level of attractiveness of the place for tourists. Therefore, any activity that affects the environment or natural resources, in the long run, aggravates attractiveness from the point of view of tourists, which leads to fewer visitors and less income from tourists. Sociocultural dimension - the social and cultural heritage of a region have a crucial role in tourism, especially in regions with particularly rich cultural and artistic heritage, or places where local tradition and values have a meaningful role. In these places, tourism can significantly contribute to creating new jobs, protecting cultural heritage, but it can also contribute to the dependence of these regions on foreign companies and tourist operators. Economic dimension - refers to the financial aspects of tourism activities that are reflected in the profit achievement, respecting the principles of the sustainable development concept. If we do not comply with the concept of sustainable development and do not consider the ecological and socio-cultural dimension, the results of future projections can distort the picture and lead to inappropriate planning.

Furthermore, sustainable tourism should (UNWTO, 2017):

- optimally use ecological resources that are a crucial element in the development of tourism, as well as maintain basic ecological processes and contribute to the preservation of natural and biological diversity;

- respect the socio-cultural authenticity of the local community, preserves its material and cultural heritage, traditional values and contributes to intercultural understanding and tolerance;

- preserve the vital and long-term goals of economic and business growth, providing socioeconomic benefits for all interested parties, employment, income and social services for the local community and contributing to poverty reduction.

Huang (2011) found that non-conventional methods of assessing tourism sustainability failed to provide reliable results. To fill this gap, numerous activities have been undertaken to develop a relatively comprehensive and logical assessment methodology (Rei- 
hanian, Hin, Kahrom, \& Mahmood, 2015; Dupeyras \& MacCallum, 2013). Some critical reasons call for an urgent assessment of the sustainability of tourism. Very poor ecological settings and cultural sensitivity of the sites call for the consistent monitoring and evaluation of the impact of tourism. In addition, the dynamic, unstable and unpredictable nature of the industry encourages the consistent implementation of the assessment and tracking progress towards sustainable tourism development (Asmelash \& Kumar, 2019).

Many tools can be used to assess the sustainable development of tourism. As one of the most widely accepted assessment tools, we indicate indicators or instruments of sustainability because they are both considered relatively reliable and easy to apply, and they contain qualitative and quantitative data. However, the absence of well-developed sustainability indicators greatly influences the adequacy of tourism sustainability assessments (Asmelash \& Kumar, 2019). Nevertheless, Reihanian et al. (2015) propose several instruments that can adequately assess the development of sustainable tourism, especially emphasising the systematic organisation and measurement of indicators, based on which the state can make adequate conclusions and decisions for the sustainable development of tourism.

It is necessary to note that most of the studies carried out on the topic of tourism sustainability assessment applied positively and negatively expressed indicators (Cottrell, Vaske, \& Roemer, 2013; Ayazlar \& Ayazlar, 2016). Thus, indicators/instruments provide an insight into the state of development of sustainable tourism, or its particular aspect, at a given point in time, but this cannot be a final assessment of the state of the given occurrence. Therefore, indicators measure information that can enable the authorities to reduce the chances of making bad decisions unconsciously (Jovičić, 2014).

Sustainable tourism is highly dependent on its ability to increase financial benefits, including the ability to maintain social, cultural, and ecological heritage (Janusz \& Bajdor, 2013). The concept of sustainable development has led to numerous controversies. The approaches are different: from those who see it as the only acceptable concept of future development to those who accept it as a theoretically conceived conception and philosophical paradigm but dispute its applicability in practice. The concept of sustainable development is directly related to the improvement of the quality of the tourist destination. The preserved natural environment, culturalhistorical heritage, positive relation of inhabitants towards tourists, cultural identity - those are the elements of the quality of a tourist destination, for which sustainable development stands. In this way, a positive interaction between tourism and the environment is created. Tourism brings revenue and part of it is invested in improving the quality of the environment. The preserved environment is an essential element of the tourist attraction of the destination.

Sustainable tourism development should maximise the benefits of tourism and, at the same time, minimise damage or costs and direct and limit tourism development in line with the requirements of sustainable tourism development. We can observe that the concept of sustainable development is based on the principle of intergenerational equity and that sustainable development requires harmonisation between economic growth, social justice, and a healthy environment. The violation of this principle causes environmental damage, which, although done today, is shifted to the next generation, endangering economic development and the development of tourism.

The population of a local community, region, entity, or country represents one of the most critical stakeholders in sustainable tourism development. If the population is not involved in the decision-making process, then the development process does not have a great chance to succeed in the long run. They will take a negative attitude about both existing and future tourism development. This paper aims to determine the perceptions of the population towards the development of tourism in Bosnia and Herzegovina from the perspective of sustainability. The research in the work was carried out based on the scientific method of deduction and analysis for the interpretation of secondary data sources, and the primary research was carried out based on the descriptive statistical analysis method. Secondary data were collected from offi- 
cial reports of tourist organisations, scientific works of experts in the field of sustainable tourism and relevant websites. Also, we obtained a list of sustainability indicators from an extended literature review and interviews with some key informants, with a particular emphasis on the European Tourism Indicator System (ETIS).

\section{Literature Review}

In recent years, sustainable development and sustainable tourism development have become a very important subject of numerous research papers around the world. Sustainability has become a significant link of tourism development, especially for tourist destinations, because the environment and its quality are an essential segment of tourist attraction (Bramwell \& Lane, 1993; Butler, 1999; Garrod \& Fyall, 1998; Stabler \& Goodall, 1997; Inskeep, 1991; Wahab \& Pigram, 1997; Hudson \& Miller, 2005; Lynn \& Brown, 2003; Ross \& Wall, 1999). The primary aim of sustainable tourism development is to provide economic benefits, to maximise visitors' satisfaction, to protect the environment and improve the quality of life of the population of the relevant destination (Akis, Peristianis, \& Warner, 1996; Aronsson, 2000; Bramwell et al., 1998; Choi \& Sirakaya, 2006; McIntyre, 1993; Mowforthand \& Munt, 2003).

Sustainable tourism development greatly facilitates and accelerates local economic development, environmental protection, as well as cultural heritage, as confirmed in numerous international resolutions and agreements (Carta di Rimini per il turismo sostenibile, 2001; European Commission, 2000, 2006, 2007; UNWTO, 1995). Also, it should be emphasised that the real effect of sustainable tourism can only be achieved if local communities and the state truly understand that sustainable tourism development greatly contributes to the improvement of social well-being (Hanafiah, Azman, Jamaluddin, \& Aminuddin, 2016).

Neto (2003) and many other authors (Godde, Price, \& Zimmermann, 200o; Milne \& Ateljevic, 2001; Wells, 1997), confirmed the positive correlation of sustainable tourism and local development, which makes it clear how vital sustainable tourism is for the local and regional development and the whole economy.
Indicators and standards for sustainable tourism development have been proposed by several organisations. In 1995, for example, the United Nations Commission for Sustainable Development (CSD) launched a five-year programme to create sustainability indicators. However, the indicators obtained were focused on the global (not local) and environmental (not cultural, economic, or institutional) dimension of sustainability (Cottrell, Vaske, \& Shen, 2007; Cottrell, Vaske, Shen \& Ritter, 2007).

UNWTO has also produced 11 key indicators for sustainable tourism, which are divided into four categories: ecological, social, economic, and planning (Cottrell et al., 2013).

The European Commission launched the European Tourism Indicator System (E TIS) in 2013 to help destinations to monitor and measure their sustainable tourism performance by using a common comparable approach. The E TIs was based on 27 core indicators and 40 optional indicators, subdivided into four categories: destination management, social, and cultural impact, economic value, environmental impact (the list indicators can be found at http://ec.europa.eu/ growth/sectors/tourism/offer/sustainable/indicators/ index_en.htm). Choi and Sirakaya (2006) also proposed six dimensions for measuring the sustainability of community-based tourism: political, social, ecological, economic, technological, and cultural indicators.

Kim, Uysal, and Sirgy (2013) believed that the perception of the well-being of the inhabitants under tourism can influence the development, and tourism policy and planning. Consequently, well-being can be used as an indicator of testing the perceptions of residents for encouraging the development of tourism. Woo, Kim, and Uysal (2015) say the population feels that life satisfaction is a key indicator for supporting sustainable tourism development. To achieve the sustainable development of community-based tourism, the population should be provided with life satisfaction sustainability such as material, emotional, health and safety, and well-being.

In their paper, Edington and Edington (1986) analysed and confirmed the impact of tourism on the environment, culture, and social and economic conditions; tourism also relies heavily on the natural and socio- 
cultural environment. Gratton and Van der Straaten (1994) also stated that sustainable tourism development is only possible when environmental capacities are not endangered.

Sustainable tourism is becoming increasingly relevant for other forms of tourism, regardless of scope, including mass tourism, which implies the fact that the concept of sustainable tourism brings together social, cultural, economic, and political alongside environmental issues (Bramwell, Higham, Lane, \& Miller, 2017). In recent years, some critical issues in sustainable tourism have changed. For example, it has been found that research and policies within sustainable tourism are too focused on the behaviour of individuals, rather than considering the broader social relationships and structures, institutional rules, and other factors. (Nunkoo, 2017; Bramwell et al., 2017; Hall, 2013).

According to Choi and Sirakaya (2005), any form of tourism development can be sustainable, but only if the population is the focal point of the mentioned development. The population attitudes are the basis for successful sustainable tourism development. Gursoy, Chi, and Dyer (2010) concluded that the population aspires to have positive attitudes towards the concept of sustainable tourism because they see tourism as a tool for economic development.

Perceptions of population can be influenced by demographic factors - age, gender, education, and years of residence (Vargas-Sánchez, Plaza-Mejia, \& PorrasBueno, 2009), community attachment (Lee, 2013), tourism planning, environmental sustainability (Choi \& Murray, 2010), the state of the local economy (Gursoy, Jurowski, \& Uysal, 2002), and the stage of tourism development (Lundberg, 2015; Hunt \& Stronza, 2014). Populations with positive perceptions will become major stakeholders in tourism planning and management (Lee \& Hsieh, 2016).

\section{Methodology}

The empirical research results, as the most important part, will be processed by descriptive statistical methods, as well as appropriate tests to compare variables within each dimension. These statistical methods will be particularly useful in the presentation of survey re- sults, for which the demographic impact on individual decisions, perceptions and preferences will be processed. The questionnaire, as the main segment of this research, consists of:

- demographic data of respondents (gender, age, education, employment);

- an open question of the eight instruments of sustainable tourism development that could best be applied in Bosnia and Herzegovina.

A Likert scale for measuring the value of attitudes with five responses provided, which are coded in numbers from one to five will be used to evaluate the attitudes of the respondents. The questionnaire will consist of open and closed questions, meaning statements with offered responses (or without intensity-yes/no answers) and statements without an offered response. The questionnaire will be implemented in written and electronic form in two ways: individual and by post (or e-mail). The survey aims to analyse and implement the concept of sustainable tourism development in Bosnia and Herzegovina.

The population (basic set) in this survey are residents of Bosnia and Herzegovina who, according to the available official data of the Agency for Statistics of Bosnia and Herzegovina, number 3,531,159 (data for 2013). The sample will be probabilistic and will be chosen by a simple random method, assuming a normal pattern of the sample and population (the sample is $n>30$, and the probability of each unit's choice is the same). Of course, such a choice will include all demographic categories of respondents who differ by gender, age, education, income. A sample that has attributes of impartiality, representativeness and economy is calculated according to the formula for calculating the minimum sample size:

$$
\begin{aligned}
n & =\frac{Z^{2} p(1-p)}{c^{2}}=\frac{1.96^{2} \cdot 0.5 \cdot(1-0.5)}{0.05^{2}} \\
& =\frac{0.9604}{0.0025}=384.16 .
\end{aligned}
$$

For the $95 \%$ level of reliability $Z=1.96$, reliability interval $(c) \pm 5 \%$, population estimation in $\mathrm{B} \& \mathrm{H}$ of $3,531,159$, response rate of $(p) 50 \%$. This led to a sample of 385 respondents. The sample rate (step) is $R=N / n=$ $2227970 / 385=5786.93$. The rate of choice or coverage 
Table 1 Statistical Analysis of Sustainable Tourism Instruments that Could be Applied in Bosnia and Herzegovina

\begin{tabular}{lrrr}
\hline Instruments & $(1)$ & $(2)$ & $(3)$ \\
\hline (1) Education of citizens about the importance of sustainable tourism & 3.71 & 1.043 & 28.11 \\
(2) Reduction of environmental pollution & 4.02 & 1.020 & 25.37 \\
(3) Maintaining natural and cultural heritage & 4.09 & 0.963 & 23.54 \\
(4) Improving tourism management & 4.02 & 0.971 & 24.15 \\
(5) Establish an integrated natural resource management system & 3.91 & 0.928 & 23.73 \\
(6) Enable the public-private partnership model & 3.85 & 0.963 & 25.01 \\
(7) Ensure active participation of all stakeholders, especially local communities, & 4.06 & 0.886 & 21.82 \\
in the creation of tourism products & & & \\
(8) Complete integration of the term sustainable tourism into strategic planning & 3.88 & 0.955 & 24.61 \\
\hline Average & 3.94 & 0.966 & 24.52 \\
\hline
\end{tabular}

Notes Column headings are as follows: (1) mean, (2) standard deviation, (3) coefficient of variation.

Table 2 Comparison of Respondents by Gender

\begin{tabular}{llrrrrrrrr}
\hline Item & & $(1)$ & $(2)$ & $(3)$ & $(4)$ & $(5)$ & $(6)$ & $(7)$ & $(8)$ \\
\hline Mean Rank & Male & 190.32 & 180.62 & 181.19 & 188.36 & 189.91 & 204.41 & 190.82 & 196.53 \\
& Female & 194.39 & 202.16 & 201.16 & 196.44 & 195.29 & 184.43 & 194.62 & 190.38 \\
\hline Mann-Whitney U test & & 17683.00 & 16097.00 & 16185.50 & 17361.50 & 17615.00 & 16251.00 & 17764.00 & 17542.50 \\
Wilcoxon W & 31213.00 & 29627.00 & 29715.50 & 30891.50 & 31145.00 & 40782.00 & 31294.00 & 42073.50 \\
Z & -0.42 & -1.98 & -1.91 & -0.75 & -0.50 & -1.82 & -0.35 & -0.56 \\
Asymp. significance (2-tailed) & 0.67 & 0.05 & 0.06 & 0.46 & 0.62 & 0.07 & 0.73 & 0.57 \\
\hline
\end{tabular}

Notes For column headings see instruments in Table 1.

of the sample by the population is $f=n / N=0.00017$ $<0.05(n>30)$.

Since a large amount of data on indicators relevant to sustainable tourism has been collected and analysed, a statistical method from general scientific methods will be used. The technique to be used in this research will be primarily cabinet or 'desk' research. An insight into the available literature in the field of research subjects (books, articles in scientific journals, collections from scientific conferences, electronic sources, etc.) will be done. The collected data were analysed using spss software. Data analysis using this software will consist of descriptive statistical methods (arithmetic mean, frequencies, standard deviation, correlation coefficient), as well as appropriate inferential statistical analyses (Mann-Whitney's U test and Kruskal-Wallis H test).

\section{Research Results}

The method of descriptive statistics was used to cover the generalities of respondents such as gender, age and education. A total of 385 people were tested. In the total sample, there were many females, but this is not significant for the purpose of the research. Of the total number of female respondents, there were 221 (57.4\%) female and 164 males (42.6\%).

Regarding age structure, the highest percentage of respondents is from 18 to 30 years old (61\%), followed by subjects aged 31 to $40(24.20 \%), 41$ to 51 years $(9.4 \%)$ and respondents over 51 years $(5+.5 \%)$. The survey included 191 persons with high school diploma, then 163 with bachelor's degrees, 30 master's degrees, and one doctor of science.

In the opinion of the population, the highest rating received an instrument that refers to the mainte- 
Table 3 Comparison of Respondents by Age

\begin{tabular}{lrrrrrrrrr}
\hline Item & & $(1)$ & $(2)$ & $(3)$ & $(4)$ & $(5)$ & $(6)$ & $(7)$ & $(8)$ \\
\hline Mean Rank & $18-30$ & 192.11 & 193.33 & 193.19 & 191.69 & 190.08 & 185.06 & 189.31 & 188.83 \\
& $31-40$ & 200.00 & 192.08 & 204.39 & 200.69 & 200.54 & 209.69 & 205.59 & 212.74 \\
& $41-50$ & 192.25 & 206.28 & 165.10 & 184.63 & 192.26 & 196.93 & 174.75 & 175.85 \\
& $50+$ & 168.10 & 170.67 & 188.21 & 187.98 & 193.55 & 201.17 & 209.76 & 181.64 \\
\hline Chi-Square & & 1.58 & 1.53 & 3.72 & 0.81 & 0.66 & 3.81 & 3.26 & 4.79 \\
Degrees of freedom & & 3 & 3 & 3 & 3 & 3 & 3 & 3 & 3 \\
Asymp. significance & & 0.66 & 0.68 & 0.29 & 0.85 & 0.88 & 0.28 & 0.35 & 0.19 \\
\hline
\end{tabular}

Notes For column headings see instruments in Table 1.

Table 4 Comparison of Respondents by Education

\begin{tabular}{llrrrrrrrr}
\hline Item & & $(1)$ & $(2)$ & $(3)$ & $(4)$ & $(5)$ & $(6)$ & $(7)$ & $(8)$ \\
\hline Mean Rank & High Sch. & 190.30 & 190.22 & 183.06 & 181.26 & 183.14 & 174.05 & 184.10 & 180.52 \\
& B Ch & 201.71 & 193.93 & 199.57 & 202.94 & 205.46 & 212.49 & 202.96 & 207.02 \\
& M C & 166.00 & 206.45 & 221.73 & 214.40 & 187.98 & 207.42 & 196.23 & 200.17 \\
& PhD & 100.00 & 169.50 & 159.00 & 172.00 & 194.50 & 203.00 & 172.00 & 78.00 \\
\hline Chi-Square & & 3.89 & 0.69 & 4.75 & 5.12 & 4.04 & 12.22 & 2.91 & 6.84 \\
Degrees of freedom & & 3 & 3 & 3 & 3 & 3 & 3 & 3 & 3 \\
Asymp. significance & & 0.27 & 0.88 & 0.19 & 0.16 & 0.26 & 0.01 & 0.41 & 0.08 \\
\hline
\end{tabular}

Notes For column headings see instruments in Table 1.

nance of natural and cultural heritage (4.09), followed by the instrument of inclusion of all stakeholders in the creation of tourism products (4.06). There are two instruments with ratings above 4 : the reduction of pollution and the improvement of tourism management. The average deviation from the average rating is 0.966 . The dispersion of the opinion of the respondents about the instruments is moderate (coefficients of variation amount to between $21 \%$ and $28 \%$ ). Non-parametric tests (Mann-Whitney's U test and Kruskal-Wallis $\mathrm{H}$ test) will be used to determine whether there are statistically significant differences between demographic groups, in the direction of instruments of sustainable tourism development can be applied in Bosnia and Herzegovina.

Based on the test results shown in Table 2, conclusions about the attitudes of men and women towards the instruments of sustainable tourism development can be drawn:
- there is no statistically significant difference in attitudes between men and women, except on the second instrument about reducing pollution of the environment, where the difference is statistically significant $p=0.047<0.05$;

- as shown in the average of the ranking of instruments, six of the eight instruments women, unlike men, considers more important.

Based on the results shown in Table 3 , it can be concluded that:

- there is no statistically significant difference between respondents in relation to their age because all values are $p>0.05$;

- respondents aged 31-40 years, unlike the other age groups, consider certain instruments of sustainable tourism development more important than the other age groups do;

- respondents aged 41-50 years, unlike the others, 
consider the reduction of pollution more important, while respondents above 50 years old consider the participation of all stakeholders in creating a sustainable tourism product to be the most important.

Based on the results shown in Table 4, it can be concluded that:

- there is no statistically significant difference between respondents in relation to their education, except on the sixth instrument (enabling the public-private partnership model) for which $p=0.007<0.05$;

- respondents with a university degree, unlike those who are categorised in the other education groups, give greater importance to certain instruments of sustainable tourism development;

- respondents with a master's degree, unlike the others, consider reducing pollution of the environment, maintaining natural and cultural heritage, and improving tourism management to be more important.

\section{Conclusion}

It is necessary to emphasise that this work is not comprehensive. Despite the contribution of this paper, which mainly refers to extending the knowledge of sustainable tourism development and makes a significant contribution to relevant literature, it has several limitations that need to be considered for future research on the assessment of tourism sustainability. The population perceptions were measured based on three dimensions (economic, socio-cultural, and environmental). To overcome this shortcoming, it is necessary to include some additional dimensions and their respective indicators such as technological sustainability, infrastructural sustainability, information, communication technology, and stakeholder collaboration. In this paper, the emphasis was placed on perceptions of local residents using a survey conducted during one year. Consequently, future research should have a long-term qualitative approach (in-depth interviews, focus groups, participative observations and ethnography). Also, this study was conducted when в \& $\mathrm{H}$ was in a politically instable time and, thus, the perception of respondents might be negatively affected.

Based on the obtained results of this empirical research, the population in Bosnia and Herzegovina has shown positive perceptions towards sustainable tourism development. All instruments of sustainable tourism development were rated with a high rating. That means that the respondents do not have an undecided attitude about their application. A priority is given to the maintenance of natural and cultural resources, as the main impetus for the implementation of sustainable tourism. Also, it can be concluded that all the population groups possess certain knowledge about sustainable development and the ways it can be applied in Bosnia and Herzegovina.

In the future development of sustainable tourism in $\mathrm{B} \& \mathrm{H}$, it is necessary to actively implement all principles of sustainable development in the ecological (preservation and protection of natural resources), the socio-cultural (protection of cultural and historical material and intangible heritage), and the economic principles of sustainable development. The economic principles of sustainable tourism development in $\mathrm{B} \& \mathrm{H}$ are easier to accomplish in big cities (Sarajevo, Banja Luka, Mostar), where there is a broad range of tourism services and facilities, and attractiveness is based largely on cultural and historical heritage.

It is vital that the future conceptualisation of sustainable tourism issues involves local communities and the public sector. If the public sector does not implement training activities and a sustainable development policy, it is difficult to expect the interest and active role of other stakeholders in the realisation of sustainable development. If the population does not recognise the benefits that a sustainable development policy will bring, the public sector and its policy will not have the support of the population.

$\mathrm{B} \& \mathrm{H}$ chronically faces the problem of a lack of quality tourism development strategies. Perhaps the biggest problem that $\mathrm{B} \& \mathrm{H}$ faces in terms of developing development strategies is the lack of understanding of the importance of long-term planning. Specifically, long-term planning implies a period of over ten years and is still rarely used in development strategies in $\mathrm{B} \& \mathrm{H}$. The lack of a long-term vision of development 
can prevent the implementation of the same. We emphasise that the sustainable development of tourism relies on a long-term perspective, and therefore requires a strategy that covers a period of more than ten years. Consequently, we can conclude that in $\mathrm{B} \& \mathrm{H}$ exist a problem of implementing the principles of sustainable tourism, both at the level of state administration and the level of local self-government.

The positive attitude of the population towards tourism development has key importance for the sustainability of tourism in this area. To guarantee the complete success of tourism development and its sustainability, it is necessary to invest in natural and cultural heritage, to ensure the active participation of all participants in the creation of tourism product and to continuously work on the education of human resources in tourism. Accordingly, the authorities responsible for the development of tourism and its planners should further devote themselves to the development of strategies and action plans for the implementation of instruments for sustainable tourism development in Bosnia and Herzegovina.

\section{References}

Akis, S., Peristianis, N., \& Warner, J. (1996). Residents' attitudes to tourism development: The case of Cyprus. Tourism Management 17(7), 481-494.

Aronsson, L. (2000). The development of sustainable tourism. London, England: Continuum.

Asmelash, A. G., \& Kumar, S. (2019). Assessing progress of tourism sustainability: Developing and validating sustainability indicators. Tourism Management, 74, 67-83.

Ayazlar, R., \& Ayazlar, G. (2016). Residents' tourism support behaviour: The role of sustainable tourism attitude. Enlightening tourism: A Path Making Journal, 6(2), 124-149.

Bramwell, B., Henry, I., Jackson, G., Prat, A., Richards, G., \& Van der Straaten, J. (1998). Sustainable tourism management. Tilburg, the Netherlands: Tilburg University Press.

Bramwell, B., Higham J., Lane B., \& Miller, G. (2017). Twentyfive years of sustainable tourism and the Journal of Sustainable Tourism: Looking back and moving forward. Sustainable Tourism, 25(1), 1-9.

Bramwell, B., \& Lane, B. (1993). Sustainable tourism: An evolving global approach. Journal of Sustainable Tourism, 1(1), 1-5.

Buckley, R. (2009). Ecotourism: Principles \& practices. Cambridge, MA: CABI Publishing.
Butler, R. W. (1999). Sustainable tourism: A state of the art review. Tourism Geographies, 1(1), 7-25.

Carta di Rimini per il turismo sostenibile. (2001). Retrieved from http://www.sigeambiente.it/dati/carta-rimini.pdf

Choi, H. C., \& Murray, I. (2010). Resident attitudes toward sustainable community tourism. Journal of Sustainable Tourism, 18(4), 575-594.

Choi, H. C., \& Sirakaya, E. (2005). Measuring residents' attitude toward sustainable tourism: Development of sustainable tourism attitude scale. Journal of Travel Research, 43(4), 380-394.

Choi, H. C., \& Sirakaya, E. (2006). Sustainability indicators for managing community tourism. Tourism Management, 27(6), 1274-1289.

Cottrell, S. P., Vaske, J. J., \& Roemer, J. M. (2013). Resident satisfaction with sustainable tourism: The case of Frankenwald Nature Park, Germany. Tourism Management Perspectives, 8, 42-48.

Cottrell, S. P., Vaske, J. J., \& Shen, F. (2007). Modeling resident perceptions of sustainable tourism development: Applications in Holland and China. China Tourism Research, 3(2), 219-234.

Cottrell, S. P., Vaske, J. J., Shen, F., \& Ritter, P. (2007). Resident perceptions of sustainable tourism in Chongdugou, China. Society and Natural Resources, 20(6), 511-525.

Dupeyras, A., \& MacCallum, N. (2013). Indicators for measuring competitiveness in tourism: A guidance document (oECD Tourism Papers 2013/O2). Paris, France: OECD Publishing.

Edington, J. H., \& Edington, M. A. (1986). Ecology, recreation and tourism. Cambridge, M A: Cambridge University Press.

European Commission. (200o). Treaty of Lisbon amending the Treaty on European Union and the Treaty establishing the European Community, signed at Lisbon, 13 December 2007. Official Journal of the European Union, c 306/1-271.

European Commission. (2006). A renewed EU tourism policy: Towards a stronger partnership for European tourism (сом(2006) 134 final). Brussels, Belgium: Commission of the European Communities.

European Commission. (2007). Agenda for a sustainable and competitive European tourism ( $\mathrm{COM}(2007) 621 \mathrm{fi}-$ nal). Brussels, Belgium: Commission of the European Communities.

Fennel, D. (2003). Ecotourism. New York, Ny: Abingdon.

Garrod, B., \& Fyall, A. (1998). Beyond the rhetoric of sustainable tourism. Tourism Management, 19(3), 199-212.

Godde, P. M., Price, M. F., \& Zimmermann, F. M. (200o). 
Tourism and development in mountain regions. Oxon, England: CA B I Publishing.

Gratton, C., \& Van der Straaten, J. (1994). The environmental impact of tourism in Europe. In C. P. Cooper \& A. Lockwood (Eds.), Progress in tourism, recreation and hospitality management (Vol. 5, pp. 147-161). Chichester, England: Wiley.

Gursoy, D., Chi, C. G., \& Dyer, P. (2010). Locals' attitudes toward mass and alternative tourism: The case of Sunshine Coast. Journal of Travel Research, 49(3), 381-394.

Gursoy, D., Jurowski, C., \& Uysal, M. (2002). Resident attitudes. Annals of Tourism Research, 29(1), 79-105.

Hall, C. M. (2013). Framing behavioural approaches to understanding and governing sustainable tourism consumption: beyond neoliberalism, 'nudging' and 'green growth'? Journal of Sustainable Tourism, 21(7), 1091-1109.

Hanafiah, M. H., Azman, I., Jamaluddin, M. R., \& Aminuddin, N. (2016). Responsible tourism practices and quality of life: Perspective of Langkawi Island communities. Procedia: Social and Behavioral Sciences, 222, 406-413.

Huang, W. (2011). Good practice in sustainable tourism: Developing a measurement system by providing a model assessment procedure (Unpublished Masters's Thesis). Lund University, Lund, Sweeden.

Hudson, S., \& Miller, G. A. (2005). The responsible marketing of tourism: The case of Canadian Mountain Holidays. Tourism Management, 26(2), 133-142.

Hunt, C., \& Stronza, A. (2014). Stage-based tourism models and resident attitudes towards tourism in an emerging destination in the developing world. Journal of Sustainable Tourism, 22(2), 279-298.

Inskeep, E. L. (1991). Tourism planning: An integrated and sustainable development approach. New York, Ny: Van Nostrand Reinhold.

Janusz, G. K., \& Bajdor, P. (2013). Towards to sustainable tourism: Framework, activities and dimensions. Procedia: Economics and Finance, 6, 523-529.

Jovičić, D. Z. (2014). Key issues in the implementation of sustainable tourism. Current Issues in Tourism, 17(4), 297302.

Kim, K., Uysal, M., \& Sirgy, M. J. (2013). How does tourism in a community impact the quality of life of community residents? Tourism Management, 36, 527-540.

Lee, T. H. (2013). Influence analysis of community resident support for sustainable tourism development. Tourism Management, 34, 37-46.

Lee, T. H., \& Hsieh, H. P. (2016). Indicators of sustainable tourism: A case study from a Taiwan's Wetland. Ecological Indicators, 67, 779-787.
Lundberg, E. (2015). The level of tourism development and resident attitudes: A comparative case study of coastal destinations. Scandinavian Journal of Hospitality and Tourism, 15(3), 266-294.

Lynn, N. A., \& Brown, R. D. (2003). Effects of recreational use impacts on hiking experiences in natural areas. Landscape and Urban Planning, 64(1-2), 77-87.

McIntyre, G. (1993). Sustainable tourism development: Guide for local planners. Madrid, Spain: World Tourism Organization.

Mihalic, T. (2016). Sustainable-responsible tourism discourse: Towards responsustable' tourism. Journal of Cleaner Production, 111(в), 461-470.

Milne, S., \& Ateljevic, I. (2001). Tourism, economic development and the globallocal nexus: Theory embracing complexity. Tourism Geographies, 3(4), 369-393.

Mowforth, M., \& Munt, I. (2003). Tourism and sustainability: Development and new tourism in the third world. London, England: Routledge.

Neto, F. (2003). A new approach to sustainable tourism development: Moving beyond environmental protection. Natural Resources Forum, 27(3), 212-222.

Nunkoo, R. (2017). Governance and sustainable tourism: What is the role of trust, power and social capital? Journal of Destination Marketing \& Management, 6(4), 277285.

Pearce, D., Markandya, A., \& Barbier, E. B. (1991). Blueprint for a green economy. London, England: Earthscan Publications.

Reihanian, A., Hin, T., Kahrom, E., \& Mahmood, N. (2015). A framework for implementing sustainable tourism in national parks of Iran: Development and use of sustainable tourism indicators in Boujagh national park, Iran. Caspian Journal of Environmental Sciences, 13(1), 41-52.

Ross, S., \& Wall, G. (1999). Ecotourism: Towards congruence between theory and practice. Tourism Management, $20(1), 123-132$.

Stabler, J. M., \& Goodall, B. (1997). Environmental awareness, action and performance in the Guernsey hospitality sector. Tourism Management, 18(1), 19-33.

Vargas-Sánchez, A., Plaza-Mejia, M. D. L. Á., \& PorrasBueno, N. (2009). Understanding residents' attitudes toward the development of industrial tourism in a former mining community. Journal of Travel Research, 47(3), $373-387$.

Vehbi, B. (2012). A model for assessing the level of tourism impacts and sustainability of coastal cities. In M. Kasimoglu \& H. Avdin (Eds.), Strategies for tourism industry (pp. 99-114). Rijeka, Croatia: InTech. 
Wahab, S., \& Pigram, J. J. (1997). Tourism, development and growth: The challenge of sustainability. New York, NY: Routledge.

Wearing, S., \& Neil, J. (2012). Ecotourism: Impacts, potentials and possibilities. New York, NY: Routledge.

Wells, M. (1997). Economic perspectives on nature tourism, conservation and development (Environmental Department Working Paper No. 55). World Bank, Washington, DC.

Woo, E., Kim, H., \& Uysal, M. (2015). Life satisfaction and support for tourism development. Annals of Tourism Research, 50, 84-97.
UNW TO. (1995). Charter for sustainable tourism. Lanzarote, Spain: World Tourism Organization.

UnwTo. (2017). Definition of sustainable development of tourism. Madrid, Spain: United Nations World Tourism Organization.

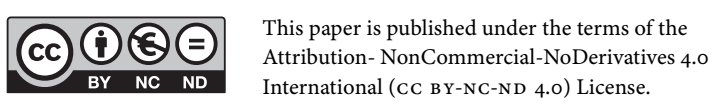

